\title{
Current and Future Therapy of Hereditary Angioedema
}

\section{(1) Öner Özdemir}

\section{Department of Pediatrics, Sakarya University Faculty of Medicine, Training and Research Hospital, Sakarya,Turkey \\ Submitted: 17.05.2019 Accepted: 10.01 .2020 \\ Correspondence: Öner Özdemir, Sakarya Üniversitesi Tıp Fakültesi, Çocuk Allerji-Immünoloji Bilim Dalı, Eğitim-Araștırma Hastanesi, Sakarya, Turkey E-mail: ozdemir_oner@hotmail.com

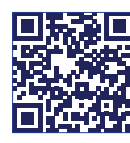 \\ Keywords: Bradykinin; $\mathrm{Cl}$ inhibitor; hereditary angioedema; kallikrein.

\begin{abstract}
Hereditary angioedema (HAE) is an autosomal dominant disorder, mostly due to $\mathrm{Cl}$ esterase inhibitor $(\mathrm{CI}-\mathrm{INH})$ deficiency, known by recurring angioedema attacks that are nonpruritic, not accompanying with urticaria, and involve the dermis, intestinal submucosa, and upper respiratory system. The angioedema attacks are not responsive to epinephrine, glucocorticoids, or antihistamine treatments. Whereas HAE patients formerly had a few therapeutic options accessible such as anabolic androgens and antifibrinolytics. Nowadays in many parts of the world there has been remarkable progress in HAE treatment for the last two decades and clinically confirmed medications are presented for prophylactic and attack treatment. Alternatives in attack therapy contain two plasma-derived $\mathrm{CI}-\mathrm{INH}$ concentrates, a recombinant $\mathrm{CI}-\mathrm{INH}$ product, a kallikrein inhibitor, and a bradykinin $\beta 2$ receptor antagonist. Options in prophylactic therapy include other than two plasma-derived $\mathrm{Cl}$ INH concentrates, subcutaneous $\mathrm{CI}-\mathrm{INH}$ replacement and newest subcutaneous plasma kallikrein inhibitor Lanadelumab. In spite of these progresses, HAE patients still run into some challenges of an arduous disorder that can yield to devastating angioedema attacks related with important expenses for patients and the public. Better education of HAE patients and implementation of the self-management policy for "on-demand" therapy will recuperate patients' life quality and negative effects of the disease. Herein the existing and promising therapeutic options are reviewed in the HAE management.
\end{abstract}

\section{INTRODUCTION}

Hereditary angioedema (HAE) is an autosomal dominant disorder, mostly due to $\mathrm{Cl}$ esterase inhibitor $(\mathrm{Cl}-\mathrm{INH})$ deficiency, known by recurring angioedema attacks that are nonpruritic, not accompanying with urticaria, and involve the dermis, intestinal submucosa, and upper respiratory system. In this review, besides the current treatment methods in the world and in our country, the drugs and treatment methods that are currently being studied in the treatment of HAE will be discussed.

As an approach to treatment, it can be considered in the first place to prevent or reduce attacks by avoiding triggering factors, if applicable. Since it is not always possible to avoid triggers, we can divide the treatment into two main groups as prophylaxis and emergency treatment. ${ }^{[1,2]}$

\section{Avoiding triggering factors}

It includes avoiding trigger factors known to the patient, such as stress, infection, trauma, certain medications (ACEinhibitor and oral contraceptives containing estrogen, etc.).

Thus, it is aimed to decrease drug use and increase the quality of life by preventing the factors that require drug use. ${ }^{[1,2]}$

\section{Treatment used in prophylaxis (protection)}

This type of treatment is divided into two as short and long-term prophylactic treatment. "Short-term prophylaxis" before planned operations, "long-term prophylaxis" may be required in cases where disease control cannot be achieved due to known conditions or personally, as will be explained below. The drugs used in this situation will be explained in detail below. ${ }^{[3-5]}$

Treatment used in emergency (attack, necessaryon demand-) situation

In cases where control cannot be achieved despite prophylactive treatment or attacks occurring in an unexpected situation and time with any trigger, urgent or need-based treatment may be required. An important point is to distinguish that it is an HAE attack in the patient not the other types of attacks like histaminergic and bradykininergic angioedema. ${ }^{[6]}$ Again, it is known that anti-histaminic, adrenaline and corticosteroids are ineffective during attacks. ${ }^{[7-9]}$

First of all, after mentioning all the drugs reported in the literature in prophylactic and emergency treatment, the drugs used in our country will be explained below in more detail. 
All drugs reported and developed in the literature

The aim is to try to control the disease by preventing the accumulation of quinine in the body that causes end products and angioedema. This is tried to be done by replacing the missing $\mathrm{CI}-\mathrm{INH}$ in the body, preventing the production of kallikrein through the coagulation system/FI 2 or the coagulation system from overworking. ${ }^{[1-9]}$

We can classify all the drugs developed so far in prophylactic and emergency treatment into eight groups below. ${ }^{[10-17]}$

I. Antifibrinolytic drugs: Epsilon $(\varepsilon)$-amino caproic acid, tranexamic acid

II. Weak (anabolic) androgens: Danazol, stanozolol, oxandrolone, methyltestosterone

III. Plasma sourced products containing $\mathrm{CI}-\mathrm{INH}$ : Plasma concentrates (Cinryze ${ }^{\circledR} /$ Berinert $^{\circledR}$ )

IV. Partially new drugs: Ecallantide (DX88, Kalbitor ${ }^{\circledR}$ ), Icatibant (Firazyr ${ }^{\circledR}$, Icatin $\left.^{\circledR}\right)$ and products containing recombinant $\mathrm{Cl}$-INH antigen (Rhucin $® /$ Ruconest $^{\circledR}$ )

V. Solvent detergent/Fresh frozen plasma

VI.Latest drugs: Subcutaneous CI-INH (Haegerda ${ }^{\circledR}$ ), subcutaneous plasma kallikrein inhibitor-Lanadelumab(Takzyhro ${ }^{\circledR}$ )

VII.Developments in clinical studies: Oral plasma kallikrein inhibitor: Avoralstat (BCX4I6I), BCX7353, KVD8I8 (KalVista Pharmacy); Containing hyaluronidase - subcutaneous $\mathrm{CI}-\mathrm{INH}$; Coagulation products that destroy FXII production (ALN-FI2, ARC-FI2) and monoclonal antibody against FXIla (CSL 3I2)

VIII.Genetic intervention methods tried in pre-clinical studies: lonis PKKRx and Gene therapy, which suppresses precallikrein transcription (anti-sense). ${ }^{[17-21]}$

\section{Different pharmaceutical groups used in other countries}

we can simply classify all drugs currently used actively in other countries in prophylactic and emergency treatment into six groups as follows.

\section{A. Antifibrinolytic drugs: Tranexamic acid}

B. Weak/anabolic androgens: Danazol

C. Products containing $\mathrm{Cl}-\mathrm{INH}$ : Plasma concentrate: Cinryze $^{\circledR}$, subcutaneous $\mathrm{Cl}-\mathrm{INH}$ (Haegerda ${ }^{\circledR}$ ) and recombinant $\mathrm{Cl}-\mathrm{INH}$ antigen (Rhucin $\circledast /$ Ruconest $^{\circledR}$ ),

D. Bradykinin receptor inhibitor: Products containing lcatibant $\left(\right.$ Firazyr $^{\circledR}$, ICATIN $^{\circledR}$ )

E. Plasma kallikrein inhibitors: Ecallantide (DX88, Kalbitor $\left.{ }^{\circledR}\right)$ administered subcutaneously and products containing Lanadelumab (Takzyhro ${ }^{\circledR}$ ) are approved drugs. ${ }^{[22-25]}$

F. Solvent detergent/fresh frozen plasma. ${ }^{[10-21]}$

In our country, there are no products containing recombinant $\mathrm{Cl}-\mathrm{INH}$ antigen, subcutaneous $\mathrm{CI}-\mathrm{INH}$ (Haegerda ${ }^{\circledR}$ ), Ecallantide (Kalbitor ${ }^{\circledR}$ ) and Lanadelumab (Takzyhro ${ }^{\circledR}$ ).

\section{Treatment methods applied in our country}

We can classify all the drugs currently used actively in our country for prophylactic and emergency treatment in six groups below.

\section{Antifibrinolytic drugs}

Although Epsilon ( $\varepsilon$ ) amino caproic acid was formerly used, afterwards it was replaced by Tranexamic acid. Tranexamic acid acts by inhibiting plasminogen activation. They are weak in strenght than androgens. It may have side effects such as diarrhea, postural hypotension, muscle cramps, retinal tumor development and liver dysfunction. Before the drug is used, the treatment should be started by making researches in terms of thrombo-embolism/thrombophilia and care should be taken in this regard during its use. ${ }^{[1-5]}$

\section{Weak/anabolic androgens}

The most commonly used one in the whole world is Danazol. Anabolic androgens act by increasing $\mathrm{Cl}-\mathrm{INH}$ synthesis in the liver. In the guides, especially for men, it is stated that written consent should be obtained from the patients due to the risk of side effects. Again, it is said that it can be used in Tanner puberty stage above 5 . As side effects, they can cause weight gain, virilization, menstrual dysfunction, liver enzyme elevation and hepatocellular adenoma. For starting Danazol therapy protocols (Milan and Budapest) have been reported. In Milan protocol, it is tried to start with a high dose (400 $\mathrm{mg} /$ day), increase up to $600 \mathrm{mg}$ if necessary, and decrease the dose to $50 \mathrm{mg} /$ day at monthly intervals to 5 days a week.

In the Budapest protocol, it is started with a partially low dose $(200 \mathrm{mg} /$ day $)$ and the dose is increased to $400 \mathrm{mg}$ if necessary, and then it is tried to be reduced to $50 \mathrm{mg} /$ day, 7 days a week at intervals of 2-4 weeks. Methyltestosterone can be tried in men when desperate. Although Stanozolol has been approved by the FDA for use in children, it is not available in or country. ${ }^{[10-17]}$ In our country, Danazol has an indication for HAE treatment.

Although easiness of the oral use of androgens and seem to be low-cost drugs, their co-morbidities such as muscle cramps, psychiatric problems, obesity, and hyperlipidemia, the indirect cost of treatment increases. ${ }^{[22]}$

The drug used orally other than danazol and tranexamic acid is Avoralstat, which is a plasma kallikrein inhibitor that has not been found successful in preventing attacks but has been found to increase quality of life. ${ }^{[23-25]}$

\section{Plasma-derived products containing recombi- nant CI-INH}

It can be used in relapse treatment, short-long term prophylaxis and pregnancy. Cinryze ${ }^{\circledR}$ in our country as plasma concentrate, Berinert ${ }^{\circledR}$ in other countries, in addition to this drug, intravenously administered recombinant $\mathrm{Cl}$ INH antigen (Rhucin/Ruconest ${ }^{\circledR}$ ) and subcutaneous $\mathrm{Cl}$ INH preparation (Haegerda ${ }^{\circledR}$ ) are available.

Products used in $\mathrm{CI}-\mathrm{INH}$ replacement therapy can be used over the age of two. $\mathrm{CI}-\mathrm{INH}$ replacement therapy in exacerbations in children $10-20$ units $/ \mathrm{kg}$, usually $500-2.000$ 
units, if $\mathrm{Cl}-\mathrm{INH}$ is administered intravenously, symptoms subside in 30-60 minutes and completely disappear within 24-48 hours. In long-term prophylaxis, I.000-2.500 units should be administered every 3-4 days, twice a week. The $\mathrm{CI}-\mathrm{INH}$ preparation should be given as a slow infusion ( $\mathrm{l} \mathrm{mL} / \mathrm{min}$ ). Side effects are rare and include symptoms such as anaphylactoid reaction (due to rapid infusion without bringing it to room temperature), formation of inhibitory antibodies against the product, localized rash, fever, headache, fatigue. ${ }^{[26,27]}$

Cinryze is an FDA-approved product for intravenous administration in lyophilized vials with 500 units $/ 5 \mathrm{~mL}$ solvent and must be stored at $+2-+8^{\circ} \mathrm{C}$. If the body weight is less than $25 \mathrm{~kg}, 500$ units, if more than $25 \mathrm{~kg}, 1.000$ units are applied. It should be melted and prepared without shaking. The prepared solution can be kept at room temperature for a maximum of 8 hours. It is administered intravenously through peripheral veins. The infusion rate should not be less than 5 minutes. Its half-life in the circulation varies between 31 and 46 hours depending on the severity of the attack. Since it is a blood product, it carries the risk of transmitting some diseases like others. ${ }^{[10,17]}$

Recombinant $\mathrm{Cl}-\mathrm{INH}$ antigen (Rhucin/Ruconest ${ }^{\circledR}$ ) is an FDA-approved preparation, especially $50 \mathrm{U} / \mathrm{kg}$ intravenously administered during attacks and has been used in the last decade. Apart from side effects such as rash and itching, there is a risk of developing anaphylaxis due to the rabbit proteins it contains. ${ }^{[28-31]}$ Currently it is still not available in our country.

Subcutaneously administered plasma-derived $\mathrm{CI}-\mathrm{INH}$ preparation Haegerda ${ }^{\circledR}$ can be used twice a week at $60 \mathrm{U} / \mathrm{kg}$ from adolescence. In studies, treatment could be reduced in to 5 years old. ${ }^{[32-37]}$ It can not be provided in Turkey.

\section{Bradykinin $\beta 2$ receptor antagonist/inhibitor}

In our country, it is an alternative to intravenous $\mathrm{CI}-\mathrm{INH}$ replacement, especially in attacks.

Subcutaneously applied lcatibant, is sold in foreign countries under the name of Firazyr ${ }^{\circledR}$ and it is produced and sold in our country under the name of Icatin ${ }^{\circledR}$.

It is not suitable for prophylaxis due to its short half-life ( $1.4 \pm 0.4$ hours) Care should be taken in terms of "rebound" effect in the treatment of attacks. Icatin is sold with a pre-filled syringe containing $30 \mathrm{mg} / 3 \mathrm{~mL}$ solution.

It was reimbursed with the Health Implementation Communiqué (SUT) at the beginning of 2019. It is easy to use and can be stored at room temperature. It has a better safety profile since it is not a blood product. Since the patient can administer the drug on his own, he can solve the problem of delay in accessing treatment. It is more economical. It is not recommended for use in pregnant women (category C). As a side effect, it may cause pain and burning at the injection site. ${ }^{[38-42]}$

lcatin is used for the treatment of HAE symptoms in adult, adolescent and pediatric patients (2 years of age, $\geq 12 \mathrm{~kg}$ ). It is applied subcutaneously. More than 3 injections should not be administered within a 24 hour period, and if more than 8 injections per month are required, the patient should be referred to a specialist. The posology reported in adults should be $30 \mathrm{mg}$ once subcutaneously, a second injection after 6 hours if necessary, and a maximum of 3 injections within 24 hours. The posology for children is based on weight. $10 \mathrm{mg}$ ( $1 \mathrm{~mL}$ ) between I2-25 kg, $15 \mathrm{mg}(1.5 \mathrm{~mL})$ between 26-40 $\mathrm{kg}, 20 \mathrm{mg}(2 \mathrm{~mL})$ between $4 \mathrm{l}-50 \mathrm{~kg}, 25 \mathrm{mg}(2.5 \mathrm{~mL})$ between $5 \mathrm{I}-65 \mathrm{~kg},>65 \mathrm{~kg} 30 \mathrm{mg}(3 \mathrm{~mL})$ can be injected.

\section{Fresh frozen plasma (ffp)}

The recommended dose for FFP administration is 10-20 $\mathrm{mL} / \mathrm{kg}, \mathrm{I}-2$ units on average. It's generally efficient for 45 minutes. It should not be ignored that in some patients the attack due to quinine substrates (precallikrein, FI 2 or kininogen residue) contained in FFP may become worse. [10-18]

After mentioning all current drugs and applied treatment methods above, the treatment methods and drugs used in prophylaxis and emergency/attack treatment will be mentioned below.

\section{Treatment methods used in prophylaxis}

It is possible to collect the prophylaxis under two subheadings (short and long term prophylaxis). Although the drugs used are similar, their timing and duration are different.

\section{Short term prophylaxis treatment}

Plasma-derived $\mathrm{CI}-\mathrm{INH}$ replacement, FFP or short-term preventive treatment with anabolic steroids may be required to prevent the development of an attack in patients who are planned to have surgery, any intervention in the mouth area, especially tooth extraction, etc. (Table I). ${ }^{[1-5,7-9]}$ Treatment approaches that can be used after minor and major procedures are summarized in Table $\mathrm{I}$.

\section{Long term prophylaxis treatment}

Although it is recommended for use in the presence of frequent and/or severe attacks, there is no generally accepted consensus. Previous guidelines were recommended for patients who had more than one attack per month or had a history of swelling in the throat, or who were absent from work for more than 5 days a month due to an attack. In recent years, it is emphasized that each patient should be evaluated at a personal level and treatment planning (personalized-individualized-treatment) should be made according to their needs. ${ }^{[2]}$

In our country, there is only one drug Cinryze ${ }^{\circledR}$ that can be used in long-term prophylaxis treatment. Other drugs such as Berinert ${ }^{\circledR}$ are expected to come. The treatment methods that can be used in the long-term prophylaxis treatment are shown in Table 2.

The newest drug in long-term prevention treatment in the world is Lanadelumab-flyo (Takzyhro ${ }^{\circledR}$ ). This product is a monoclonal antibody, functions by inhibiting plasma kallikrein and although it is not included in the guidelines, it was approved for use by the FDA on August 23, 2018. ${ }^{[43-45]}$ 
Table I. Drugs recommended in current guidelines for short-term prophylaxis (10-17)

\begin{tabular}{|c|c|c|c|c|c|}
\hline Product & Trade Name & Dose & Source & Medication & Explanation \\
\hline \multicolumn{6}{|l|}{ Minor operations } \\
\hline pdCI-INH & Berinert/Cinryze & $\begin{array}{l}20 \text { IU/kg; } \\
\text { I.000Ü }\end{array}$ & Plasma & IV & $\begin{array}{l}\text { If it is on } \\
\text { hand, no other } \\
\text { medicine is needed }\end{array}$ \\
\hline Danazol & Danasin & $\begin{array}{c}2.5-10 \\
\mathrm{mg} / \mathrm{kg} / \text { day }\end{array}$ & - & Oral & $\begin{array}{l}5 \text { days before - } 5 \text { days } \\
\text { after the procedure }\end{array}$ \\
\hline Stanazolol & Winstrol & $4-6 \mathrm{mg} / \mathrm{kg} / \mathrm{day}$ & - & Oral & $\begin{array}{l}5 \text { days before - } 5 \text { days } \\
\text { after the procedure }\end{array}$ \\
\hline Traneksamik acid & Transamin & $75 \mathrm{mg} / \mathrm{kg} /$ day & - & Oral & $\begin{array}{l}5 \text { days before - } 5 \text { days } \\
\text { after the procedure }\end{array}$ \\
\hline \multicolumn{6}{|l|}{ Major operations } \\
\hline pdCI-INH & Berinert/Cinryze & $\begin{array}{c}20 \mathrm{IU} / \mathrm{kg} ; \\
500-I 500 \mathrm{U}\end{array}$ & Plasma & IV & $\begin{array}{c}\text { 1-6 hours before the } \\
\text { procedure }\end{array}$ \\
\hline \multicolumn{6}{|l|}{ Solvent-detergent / } \\
\hline Fresh frozen plasma & SDP/TDP & $\begin{array}{c}10 \mathrm{~mL} / \mathrm{kg} ; \\
400-800 \mathrm{~mL} \\
(2-4 \mathrm{U})\end{array}$ & Plasma & IV & $\begin{array}{c}\text { I-6 hours before the } \\
\text { procedure }\end{array}$ \\
\hline
\end{tabular}

PI: Plasma-induced; CI-INH: CI esterase inhibitor; IV: Intravenous; SC: Subcutan.

Table 2. Drug groups recommended in current guidelines for long-term prophylaxis (10-17)

\begin{tabular}{|c|c|c|c|c|}
\hline Group & Trade Name & Dose & Medication & Explanation \\
\hline $\mathrm{pdCl}-\mathrm{INH}$ & Berinert/Cinryze & $\begin{array}{l}\text { I.000-2.500 Ü, } \\
2 \text { times a week }\end{array}$ & IV & $\begin{array}{c}\text { The most known druf; } \\
\text { Plasma sourced; } \\
\text { Available in } 2 \\
\text { preparations }\end{array}$ \\
\hline $\mathrm{CI}-\mathrm{INH}$ & Haegarda & $\begin{array}{c}60 \mathrm{IU} / \mathrm{kg} \\
2 \text { times a week }\end{array}$ & SC & $\begin{array}{c}\text { New drug; Plasma } \\
\text { sourced }\end{array}$ \\
\hline Kallikrein inhibitor & Lanadelumab & $150 \mathrm{mg} /$ day & SC & $\begin{array}{c}\text { August } 2018 \text { FDA } \\
\text { approved }\end{array}$ \\
\hline Antifibrinolytic & Tranexynamic acid & $\begin{array}{c}20-50 \mathrm{mg} / \mathrm{kg} / \text { day } \\
3-6 \mathrm{~g} / \text { day }\end{array}$ & Oral & $\begin{array}{l}\text { If lack of } \mathrm{Cl} \text {-INH } \\
\text { or if, androgen } \\
\text { contraindicated }\end{array}$ \\
\hline Antifibrinolytic & $\mathcal{E}$-amino caproic acid & 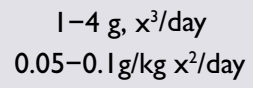 & Oral & $\begin{array}{l}\text { It is used of lack of } \\
\text { Tranexynamic acid }\end{array}$ \\
\hline Androgens & Danazol & $\begin{array}{c}2.5-5 \mathrm{mg} / \mathrm{kg} / \text { day } \\
\leq 200 \mathrm{mg} / \text { day }\end{array}$ & Oral & $\begin{array}{l}\text { It can not be used } \\
\text { during pregnancy } \\
\text { and before Tanner } \\
\text { phase } 5\end{array}$ \\
\hline Androgens & Stanozolol & $0.5-2 \mathrm{mg} / \mathrm{day}$ & Oral & $\begin{array}{l}\text { Attention to } \\
\text { Virilizan effects }\end{array}$ \\
\hline Androgens & Oksandrolon & $\begin{array}{c}0.1 \mathrm{mg} / \mathrm{kg} / \text { day } \\
10 \mathrm{mg} / \text { day }\end{array}$ & Oral & $\begin{array}{l}\text { Attention to side } \\
\text { effects }\end{array}$ \\
\hline
\end{tabular}

PD: Plasma induced; CI-INH: Cl esterase inhibitor; IV: Intravenous; SC: Subcutan, FDA: America food medicine department.

Emergency/attack (acute, when required: on demand) treatment

It is very important for the patient deciding "What/in what kind of involvement should the treatment be given in emergency attack (acute) treatment?" A wait-and-see strategy can be used for skin swelling in the trunk and extremities, except for facial and neck involvement. In attacks involving the larynx and abdomen, there is no need to wait and attack treatment should be started quickly. ${ }^{[11,13]}$

As in every emergency case, ensuring the patient's airway 
Table 3. Drugs recommended in current guidelines in acute (attack) treatment

\begin{tabular}{|c|c|c|c|c|c|}
\hline Group & Trade Name & Dose & Source & Medication & Side effect \\
\hline $\mathrm{pdCl}-\mathrm{INH}$ & Berinert/Cinryze & $20 \mathrm{IU} / \mathrm{kg} ; 1.000 U ̈$ & Plasma & IV & $\begin{array}{c}\text { Thrombosis, } \\
\text { infection }\end{array}$ \\
\hline rhCl-INH & Ruconest/Rhucin & $50 \mathrm{IU} / \mathrm{kg}$ & Recombinant & IV & Anaphylaxis \\
\hline Icatibant & Icatin/Firazyr & 30 mg & - & SC & $\begin{array}{l}\text { Injection } \\
\text { reaction }\end{array}$ \\
\hline Ecallantide & Kalbitor & $30 \mathrm{mg}$ & - & SC & Anaphylaxis \\
\hline Solvent-detergent/ & SDP/TDP & 10 mL/kg; & Plasma & IV & It can increase \\
\hline Fresh frozen plasma & & $400-800 \mathrm{~mL}$ & & & $\begin{array}{l}\text { the severity of } \\
\text { the attack! }\end{array}$ \\
\hline
\end{tabular}

PD: Plasma induced, $\mathrm{CI}-\mathrm{INH}: \mathrm{Cl}$ esterase inhibitor; IV: Intravenous, SC: Subcutan.

clearance comes first. Today, especially 4 kinds of drugs $\mathrm{Cl}-\mathrm{INH}$ plasma concentrate, recombinant $\mathrm{CI}-\mathrm{INH}$, Icatibant and Ecallantide are used all over the world. Supportive therapy with fluid replacement and analgesics can be given, if appropriate. It may be preferred if solvent-detergent plasma is available, otherwise fresh frozen plasma can be given instead. ${ }^{[10-12,15-17]}$

Although androgens and antifibrinolytic drugs have been used in the past, they have been abandoned today as they seem less effective than new drugs. The effect of Danazol treatment begins within I to 2 days on average. For this reason, although it is considered not a good option in the treatment of relapses, as a general approach, it is recommended that patients in long-term prophylaxis treatment should double the dose of danazol treatment in case of an attack, despite the dose they use. Although less effective in comparison, Tranexamic acid can be tried in situations where other drugs are not available. ${ }^{[13,46-50]}$

In our country, $\mathrm{Cl}-\mathrm{INH}$ plasma concentrates, which have been used for the last two decades, can be given. Also, lcatibant (bradykinin receptor $\beta 2$ antagonist), which is newly brought to our country, can be used as an alternative. If none is found, fresh frozen plasma can be given (Table 3). ${ }^{[13]}$ Kallikrein inhibitor: Ecallantide (DX88, Kalbitor) was brought to our country at some time, it is now withdrawn from the market. ${ }^{[4]}$ The treatment methods that can be used in the treatment of attacks are shown in Table 3.

\section{Some treatment applications with the new drugs}

In the reviews published in 2019 , recombinant Rhucin $^{\circledR} / \mathrm{Ru}$ conest $^{\circledR}(50 \mathrm{lU} / \mathrm{kg})$ given intravenously in acute treatment and plasma-derived Haegarda ${ }^{\circledR}(60 \mathrm{lU} / \mathrm{kg})$ administered subcutaneously in prophylaxis treatment were included in the texts. ${ }^{[52]}$

Recombinant cl-inh (rhucin/ruconest ${ }^{\circledR}$ ) products: Although it has been used in adolescents since the last decade and have been introduced in the guidelines, trial studies are continuing to reduce the age of indication in treatment to 5-14 years. ${ }^{[28-31]}$

Subcutaneous cl-inh (haegarda ${ }^{\circledR}$ ) product: Haegarda, one of the new alternatives for long-term prophylaxis, was approved in 2017. Dose safety studies are ongoing. Again, this plasma-derived product was compared with intravenous $\mathrm{Cl}-\mathrm{INH}$ replacement $\left(\mathrm{Cinryze}^{\circledR}\right.$ ) and was found more successful. Studies conducted to teach the use of this subcutaneous $\mathrm{CI}-\mathrm{INH}$ replacement at home, have also been found successful. ${ }^{[32-36]}$ Treatment trials of subcutaneous $\mathrm{Cl}-\mathrm{INH}$ (rHuPH20) replacement containing hyaluronidase were stopped due to the development of non-neutralizing antibodies. ${ }^{[37]}$

\section{The most known side effects of treatment}

It should be kept in mind that, intravenous blood product plasma-derived $\mathrm{Cl}-\mathrm{INH}$ products such as Cinryze ${ }^{\circledR}$, Berinert ${ }^{\circledR}$ carry a risk of viral disease transmission, although have not been reported to date. It should be known that, products such as recombinant Rhucin $^{\circledR} /$ Ruconest $^{\circledR}$ may cause anaphylaxis as a result of the hypersensitivity reaction they may develop against rabbit proteins. Ecallantide is also known for its ability to cause hypersensitivity reactions, including anaphylaxis. Icatibant is mostly known for the reactions at the injection site. ${ }^{[7-17]}$

\section{Future treatment in hereditary angioedema}

Here, we will briefly discuss the clinical and pre-clinical drugs and methods that are being developed for the treatment. In particular, clinical studies on plasma kallikrein inhibitors continue intensely.

\section{Possible future treatment methods tried in the clinic}

Subcutaneous plasma kallikrein inhibitor Lanadelumab (Takzyhro ${ }^{\circledR}$ ): In a study of 125 patients, with this product, it was observed that it significantly reduced attacks and increased quality of life. ${ }^{[45]}$

Oral plasma kallikrein inhibitor Avoralstat (BCX4 I6I): In the trials performed with an oral plasma kallikrein inhibitor, it was shown that it could not prevent attacks, but increased angioedema quality of life scores. ${ }^{[23]}$

Oral plasma kallikrein inhibitor BCX7353: Another oral plasma kallikrein inhibitor, in a study of 72 patients with a dose of $\geq 125 \mathrm{mg} /$ day, was reported to reduce the number of attacks and positively affected the quality of life. In the 
study, mostly side effects related to the gastrointestinal system were reported. ${ }^{[25]}$

\section{Possible future application pre-clinically tried genetic treatment methods}

Preclinical studies are based on the destruction of the production of kallikrein and coagulation FI2 in the body and ultimately to prevent the formation of angioedema by reducing the accumulation of quinine in the body. ${ }^{[21]}$

Ionis PKKRx: This treatment method, produced by the company lonis, performs kallikrein inhibition over the anti-sense oligonucleotide that suppresses the precallikrein transcription. ${ }^{[18,21]}$

ALN-FI 2: A product called ALN-FI2, a double-stranded small RNA interference (RNAi) drug produced by Alnylam Pharmacy, is trying to be developed. It is a method intended to be used in HAE prophylaxis and based on destroying the synthesis of Factor XII. ${ }^{[18,21]}$

ARC-F I2: Another drug developed by the Arrowhead Research Company and named as ARC-FI2, is a product coded as ARC-FI2 that acts on RNAi. Studies in mouse models have shown that the production of Factor XII is $>90 \%$ inhibited with monthly injection of $4 \mathrm{mg} /$ $\mathrm{kg}$ ARC-FI2. As a result of this treatment, it was reported that the swelling in the paw of the mouse was statistically significantly reduced. ${ }^{[18]}$

Gene therapy: In a study reported by Qiu et al. ${ }^{[51]}$ in 2018, trial studies were conducted with the Adenoviral vector in HAE mouse models with $\mathrm{CI}-\mathrm{INH}$ deficiency, and it provided $\mathrm{CI}-\mathrm{INH}$ production in mice above the expected therapeutic level and this method was shown to be useful in protecting against long-term disease. ${ }^{[21.51]}$

Peer-review

Internally peer-reviewed.

Conflict of Interest

None declared.

\section{REFERENCES}

1. Frank MM, Zuraw B, Banerji A, Bernstein JA, Craig T, Busse P, et al; US Hereditary Angioedema Association Medical Advisory Board. Management of Children With Hereditary Angioedema Due to C1 Inhibitor Deficiency. Pediatrics 2016;138:e20160575. [CrossRef]

2. Nasr IH, Manson AL, Al Wahshi HA, Longhurst HJ. Optimizing hereditary angioedema management through tailored treatment approaches. Expert Rev Clin Immunol 2016;12:19-31. [CrossRef]

3. Longhurst H, Zinser E. Prophylactic Therapy for Hereditary Angioedema. Immunol Allergy Clin North Am 2017;37:557-70.

4. Greve J, Strassen U, Gorczyza M, Dominas N, Frahm UM, Mühlberg $\mathrm{H}$, et al. Prophylaxis in hereditary angioedema (HAE) with $\mathrm{C} 1$ inhibitor deficiency. J Dtsch Dermatol Ges 2016;14:266-75. [CrossRef]

5. Craig T, Busse P, Gower RG, Johnston DT, Kashkin JM, Li HH, et al. Long-term prophylaxis therapy in patients with hereditary angioedema with C1 inhibitor deficiency. Ann Allergy Asthma Immunol 2018;121:673-9. [CrossRef]

6. Özdemir Ö. Herediter anjioödemde tanı ve ayırıcı tanı. Turkiye Klinikleri J Allergy-Special Topics 2011;4:21-35.
7. Sabharwal G, Craig T. Pediatric hereditary angioedema: an update. F1000Res 2017 Jul 24;6:F1000-1205. [CrossRef]

8. Pattanaik D, Lieberman JA. Pediatric Angioedema. Curr Allergy Asthma Rep 2017:17:60. [CrossRef]

9. MacGinnitie AJ. Pediatric hereditary angioedema. Pediatr Allergy Immunol 2014;25:420-7. [CrossRef]

10. Bowen T, Cicardi M, Farkas H, Bork K, Kreuz W, Zingale L, et al. Canadian 2003 International Consensus Algorithm For the Diagnosis, Therapy, and Management of Hereditary Angioedema. J Allergy Clin Immunol 2004;114:629-37. [CrossRef]

11. Bowen T, Cicardi M, Farkas H, Bork K, Longhurst HJ, Zuraw B, et al. 2010 International consensus algorithm for the diagnosis, therapy and management of hereditary angioedema. Allergy Asthma Clin Immunol 2010;6:24. [CrossRef]

12. Lang DM, Aberer W, Bernstein JA, Chng HH, Grumach AS, Hide M, et al. International consensus on hereditary and acquired angioedema. Ann Allergy Asthma Immunol 2012;109:395-402. [CrossRef]

13. Moellman JJ, Bernstein JA, Lindsell C, Banerji A, Busse PJ, Camargo $\mathrm{CA} \mathrm{Jr}$, et al. A consensus parameter for the evaluation and management of angioedema in the emergency department. Acad Emerg Med 2014;21:469-84. [CrossRef]

14. Zuraw BL, Bernstein JA, Lang DM, Craig T, Dreyfus D, Hsieh F, et al; American Academy of Allergy, Asthma and Immunology; American College of Allergy, Asthma and Immunology. A focused parameter update: hereditary angioedema, acquired $\mathrm{C} 1$ inhibitor deficiency, and angiotensin-converting enzyme inhibitor-associated angioedema. J Allergy Clin Immunol 2013;131:1491-3. [CrossRef]

15. Cicardi M, Aberer W, Banerji A, Bas M, Bernstein JA, Bork K, et al; HAWK under the patronage of EAACI (European Academy of Allergy and Clinical Immunology). Classification, diagnosis, and approach to treatment for angioedema: consensus report from the Hereditary Angioedema International Working Group. Allergy 2014;69:602-16. [CrossRef]

16. Jose J, Zacharias J, Craig T. Review of Select Practice Parameters, Evidence-Based Treatment Algorithms, and International Guidelines for Hereditary Angioedema. Clin Rev Allergy Immunol 2016;51:193-206.

17. Maurer M, Magerl M, Ansotegui I, Aygören-Pürsün E, Betschel S, Bork $\mathrm{K}$, et al. The international WAO/EAACI guideline for the management of hereditary angioedema-The 2017 revision and update. Allergy 2018;73:1575-96. [CrossRef]

18. Chen M, Riedl MA. Emerging Therapies in Hereditary Angioedema. Immunol Allergy Clin North Am 2017;37:585-95. [CrossRef]

19. Lumry WR. Current and emerging therapies to prevent hereditary angioedema attacks. Am J Manag Care 2018;24(14 Suppl):S299-S307.

20. Perego F, Wu MA, Valerieva A, Caccia S, Suffritti C, Zanichelli A, et al. Current and emerging biologics for the treatment of hereditary angioedema. Expert Opin Biol Ther 2019;19:517-26. [CrossRef]

21. Farkas H. Hereditary angioedema: examining the landscape of therapies and preclinical therapeutic targets. Expert Opin Ther Targets 2019;23:457-9. [CrossRef]

22. Tse KY, Zuraw BL, Chen Q, Christiansen SC. Anabolic androgen use in the management of hereditary angioedema: Not so cheap after all. Ann Allergy Asthma Immunol 2017;118:456-460.e1. [CrossRef]

23. Riedl MA, Aygören-Pürsün E, Baker J, Farkas H, Anderson J, Bernstein JA, et al. Evaluation of avoralstat, an oral kallikrein inhibitor, in a Phase 3 hereditary angioedema prophylaxis trial: The OPuS-2 study. Allergy 2018;73:1871-80. [CrossRef]

24. Banerji A, Busse P, Shennak M, Lumry W, Davis-Lorton M, Wedner HJ, et al. Inhibiting Plasma Kallikrein for Hereditary Angioedema Prophylaxis. N Engl J Med 2017;376:717-28. [CrossRef]

25. Aygören-Pürsün E, Bygum A, Grivcheva-Panovska V, Magerl M, Graff J, Steiner UC, et al. Oral Plasma Kallikrein Inhibitor for Prophylaxis in Hereditary Angioedema. N Engl J Med 2018;379:352-62. 
26. Zanichelli A, Azin GM, Cristina F, Vacchini R, Caballero T. Safety, effectiveness, and impact on quality of life of self-administration with plasma-derived nanofiltered $\mathrm{C} 1$ inhibitor $\left(\right.$ Berinert $\left.^{\circ}\right)$ in patients with hereditary angioedema: the SABHA study. Orphanet J Rare Dis 2018;13:51.

27. Henry Li H, Riedl M, Kashkin J. Update on the Use of C1-Esterase Inhibitor Replacement Therapy in the Acute and Prophylactic Treatment of Hereditary Angioedema. Clin Rev Allergy Immunol 2019;56:207-18. [CrossRef]

28. Bernstein JA, Relan A, Harper JR, Riedl M. Sustained response of recombinant human $\mathrm{C} 1$ esterase inhibitor for acute treatment of hereditary angioedema attacks. Ann Allergy Asthma Immunol 2017;118:452-5. [CrossRef]

29. Baker JW, Reshef A, Moldovan D, Harper JR, Relan A, Riedl MA. Recombinant Human C1-Esterase Inhibitor to Treat Acute Hereditary Angioedema Attacks in Adolescents. J Allergy Clin Immunol Pract 2017;5:1091-7. [CrossRef]

30. Li HH, Reshef A, Baker JW, Harper JR, Relan A. Efficacy of recombinant human $\mathrm{C} 1$ esterase inhibitor for the treatment of severe hereditary angioedema attacks. Allergy Asthma Proc 2017;38:456-61.

31. Riedl MA, Li HH, Cicardi M, Harper JR, Relan A. Recombinant human $\mathrm{C} 1$ esterase inhibitor for acute hereditary angioedema attacks with upper airway involvement. Allergy Asthma Proc 2017;38:462-6.

32. Craig T, Zuraw B, Longhurst H, Cicardi M, Bork K, Grattan C, et al. Long-Term Outcomes with Subcutaneous C1-Inhibitor Replacement Therapy for Prevention of Hereditary Angioedema Attacks. J Allergy Clin Immunol Pract 2019;7:1793-802.e2.

33. Bernstein JA, Li HH, Craig TJ, Manning ME, Lawo JP, Machnig T, et al. Indirect comparison of intravenous vs. subcutaneous C1-inhibitor placebo-controlled trials for routine prevention of hereditary angioedema attacks. Allergy Asthma Clin Immunol 2019;15:13.

34. Craig T, Lumry W, Cicardi M, Zuraw B, Bernstein JA, Anderson J, et al; COMPACT Investigators. Treatment effect of switching from intravenous to subcutaneous $\mathrm{C} 1$-inhibitor for prevention of hereditary angioedema attacks: COMPACT subgroup findings. J Allergy Clin Immunol Pract 2019;7:2035-8. [CrossRef]

35. Murphy E, Donahue C, Omert L, Persons S, Tyma TJ, Chiao J, Lumry W. Training patients for self-administration of a new subcutaneous C1-inhibitor concentrate for hereditary angioedema. Nurs Open 2018;6:126-35. [CrossRef]

36. Longhurst H, Cicardi M, Craig T, Bork K, Grattan C, Baker J, et al. Prevention of Hereditary Angioedema Attacks with a Subcutaneous C1 Inhibitor. N Engl J Med 2017;376:1131-40. [CrossRef]

37. Riedl MA, Lumry WR, Li HH, Banerji A, Bernstein JA, Ba M, et al. Subcutaneous administration of human $\mathrm{C} 1$ inhibitor with recombinant human hyaluronidase in patients with hereditary angioedema. Allergy Asthma Proc 2016;37:489-500. [CrossRef]

38. Caballero T, Aberer W, Longhurst HJ, Maurer M, Zanichelli A, Per- rin A, et al; IOS Study Group. The Icatibant Outcome Survey: experience of hereditary angioedema management from six European countries. J Eur Acad Dermatol Venereol 2017;31:1214-22. [CrossRef]

39. Longhurst HJ, Zanichelli A, Caballero T, Bouillet L, Aberer W, Maurer M, et al; IOS Study Group. Comparing acquired angioedema with hereditary angioedema (types I/II): findings from the Icatibant Outcome Survey. Clin Exp Immunol 2017;188:148-53. [CrossRef]

40. Lumry WR, Farkas H, Moldovan D, Toubi E, Baptista J, Craig T, et al. Icatibant for Multiple Hereditary Angioedema Attacks across the Controlled and Open-Label Extension Phases of FAST-3. Int Arch Allergy Immunol 2015;168:44-55. [CrossRef]

41. Farkas H, Reshef A, Aberer W, Caballero T, McCarthy L, Hao J, et al. Treatment Effect and Safety of Icatibant in Pediatric Patients with Hereditary Angioedema. J Allergy Clin Immunol Pract 2017;5:1671-8.e2. [CrossRef]

42. Longhurst HJ, Aberer W, Bouillet L, Caballero T, Maurer M, Fabien V, et al; IOS Study Group. The Icatibant Outcome Survey: treatment of laryngeal angioedema attacks. Eur J Emerg Med 2016;23:224-7.

43. Busse PJ, Farkas H, Banerji A, Lumry WR, Longhurst HJ, Sexton DJ, et al. Lanadelumab for the Prophylactic Treatment of Hereditary Angioedema with C1 Inhibitor Deficiency: A Review of Preclinical and Phase I Studies. BioDrugs 2019;33:33-43. [CrossRef]

44. Syed YY. Lanadelumab: First Global Approval. Drugs 2018;78:1633-7.

45. Banerji A, Riedl MA, Bernstein JA, Cicardi M, Longhurst HJ, Zuraw BL, et al. Effect of Lanadelumab Compared With Placebo on Prevention of Hereditary Angioedema Attacks: A Randomized Clinical Trial. JAMA 2018;320:2108-21. [CrossRef]

46. Baysan A, Güleç M. Herediter anjioödemde atakların önlenmesi. Turkiye Klinikleri J Allergy-Special Topics 2011;4:36-43.

47. Akkor Gelincik A. Herediter anjioödemde akut atakların tedavisi. Turkiye Klinikleri J Allergy- Special Topics 2011;4:44-50.

48. Duffey H, Firszt R. Management of acute attacks of hereditary angioedema: role of ecallantide.J Blood Med 2015;6:115-23. [CrossRef]

49. Katelaris CH. Acute Management of Hereditary Angioedema Attacks. Immunol Allergy Clin North Am 2017;37:541-56. [CrossRef]

50. Otani IM, Christiansen SC, Busse P, Camargo CA Jr, Zuraw BL, Riedl MA, et al. Emergency Department Management of Hereditary Angioedema Attacks: Patient Perspectives. J Allergy Clin Immunol Pract 2017;5:128-34.e4. [CrossRef]

51. Qiu T, Chiuchiolo MJ, Whaley AS, Russo AR, Sondhi D, Kaminsky SM, et al. Gene therapy for C1 esterase inhibitor deficiency in a Murine Model of Hereditary angioedema. Allergy 2019;74:1081-9.

52. Henry Li H, Riedl M, Kashkin J. Update on the Use of C1-Esterase Inhibitor Replacement Therapy in the Acute and Prophylactic Treatment of Hereditary Angioedema. Clin Rev Allergy Immunol 2019;56:207-18. [CrossRef]

\section{Günümüz ve Gelecekte Herediter Anjiyoödem Tedavisi}

Çoğunlukla $\mathrm{Cl}$ esteraz inhibitör ( $\mathrm{Cl}-\mathrm{INH})$ eksikliğine bağlı meydana gelen herediter anjiyoödem (HAÖ) cilt, bağırsak submukozası ve üst solunum yolunu tutan; kaşıntı ve ürtikerle birlikte olmadan tekrarlayan anjiyoödem ataklarıyla seyreden otozomal dominant bir hastalıktır. Herediter anjiyoödem atakları epinefrin, glukokortikoit veya antihistaminik tedavisine cevapsızdır. Herediter anjioödem hastaları önceden anabolik androjen ve antifibrinolitikler gibi birkaç tedavi seçeneğine sahipti. Günümüzde birçok ülkede HAÖ tedavisinde son 20 yıldır belirgin ilerleme olmuş ve klinikte etkinliği kanıtlanmış atak ve profilaktik tedavide kullanılan ilaçlar piyasaya sunulmuştur. Atak tedavisinde alternatifler plazmadan üretilen iki CI-INH konsantresini, rekombinan $\mathrm{CI}-\mathrm{INH}$ ürününü, kallikrein inhibitörü ve bradikinin $\beta 2$ reseptör antagonistini içerir. Profilaksi tedavi seçenekleri plazmadan üretilen iki plazma kaynaklı $\mathrm{CI}-\mathrm{INH}$ konsantresi dışında, subkutan $\mathrm{Cl}-\mathrm{INH}$ replasmanını ve en yeni subkutan plazma kallikrein inhibitörü Lanadelumab'ı içerir. Bu gelişmelere rağmen, HAÖ hastaları hasta ve toplum için önemli derecede maliyetle ilişkili ve yıkıcı anjioödem ataklarına yol açan bu zorlu hastalı̆ıı hala bazı ciddi sorunlarıyla karşılaşmaktadır. Hastalarının daha iyi eğitimi ve gereğinde tedavi için kendi kendine tedavi stratejisinin yerleşmesi hastaların yaşam kalitesi ve hastalı̆ı̆n negatif etkilerini düzeltir. Bu yazıda, HAÖ tedavisinde mevcut olan ve ümit vaat eden tedavi seçenekleri gözden geçirildi.

Anahtar Sözcükler: Bradikinin; $\mathrm{Cl}$ inhibitör; herediter anjiyoödem; kallikrein. 